\title{
The Intuitive Thinking Ability of Students of Grade XI Science at SMA Negeri 4 Palu through the Implementation of Discovery Learning Model on Colloidal Material
}

\author{
* Muh. Fahry Ince Ote, Paulus Hengky Abram \& Purnama Ningsih \\ Pendidikan Kimia/FKIP - Universitas Tadulako, Palu - Indonesia 94119 \\ Received 10 December 2019, Revised 12 January 2019, Accepted 10 February 2020 \\ doi: 10.22487/j24775185.2020.v9.i1.pp22-26
}

\begin{abstract}
This study aimed to describe the intuitive thinking ability in Grade XI SMA Negeri 4 Palu through the implementation of discovery learning model on Colloidal material. This study was a One-Shot Case Study design. The population of this study was all students of grade XI Science at SMA Negeri 4 Palu, and the sample was Class XI Science 3 as the replication class 1 and class XI Science 6 as the replication class 2. The results obtain the intuitive thinking ability of replication class 1 is that the students who solved the problem with a reasonable answer, that is $86.43 \%$ in the very high category. Students who solved problems using prior knowledge and experience, that is equal to $77.14 \%$ in the high category, and students who solved problems based on generalization of examples or concepts, that is $84.46 \%$ in the very high category. While the intuitive thinking ability of replication class 2 is that the students who solved problems with a reasonable answer is $52.85 \%$, in the medium category. Students who solved problems using prior knowledge and experience, that is equal to $76.42 \%$ included in the high category, and students who solved problems based on generalization of examples or concepts that is equal to $83.92 \%$ in the very high category.
\end{abstract}

Keywords: Discovery learning, intuitive thinking, colloid

\section{Pendahuluan}

Kurikulum 2013 mengisyaratkan bahwa dalam proses pembelajaran siswa diarahkan dapat memiliki keterampilan berpikir tingkat tinggi atau higher order thinking skill (HOTS). Hal ini sejalan dengan pendapat Swart, bahwa keterampilan berpikir memiliki posisi yang penting dalam pembelajaran. Kegiatan belajar harus dapat memotivasi siswa untuk mencapai kompetensi yang telah ditetapkan secara optimal dan diharapkan dapat mengembangkan potensi siswa agar dapat berpikir tingkat tinggi. Akan tetapi, pada kenyataannya dalam proses pembelajaran masih dijumpai kurangnya keterlibatan siswa dalam kegiatan pembelajaran, sehingga sulit untuk mencapai kompetensi yang telah ditetapkan, Salah satu contoh adalah pembelajaran kimia (Rahmi \& Alberida, 2017).

Kimia merupakan salah satu bidang kajian Ilmu Pengetahuan Alam (IPA) yang sudah diperkenalkan kepada siswa sejak dini. Mata pelajaran kimia menjadi sangat penting kedudukannya dalam masyarakat karena kimia berada disekitar kehidupan sehari-hari. Adanya kesulitan siswa terhadap pelajaran kimia dapat disebabkan oleh dua faktor, yaitu faktor internal dan faktor eksternal (Slameto, 2013).
Siswa berpendapat pelajaran kimia merupakan pelajaran yang sulit dan kurang diminati sehingga mengalami kesulitan dalam belajar. Permasalahan tersebut dikarenakan oleh model pembelajaran yang digunakan guru tidak mengaitkan dalam permasalahan kehidupan seharihari. Guru biasanya mengajar hanya dengan menjelaskan hasil temuan yang sudah jadi tanpa menjelaskan darimana hasil tersebut berasal, sehingga kemampuan berpikir siswa berada pada level yang rendah (Haeruman dkk., 2017). Sitrait \& Hutabarat (2015) menyatakan bahwa sulitnya siswa memahami dan menerapkan konsep-konsep kimia menyebabkan siswa mengambil langkah tercepat dengan cara menghafal.

Konsep dalam ilmu kimia bersifat abstrak dan saling berkaitan, termasuk pada materi koloid. Materi koloid adalah materi pembelajaran dalam ilmu kimia yang memerlukan pemahaman konseptual, nyata dan banyak ditemukan dalam kehidupan sehari-hari (Sari dkk., 2016). Menurut pendapat Isnainiyah dkk., (2015) konsep yang abstrak cocok bila dibelajarkan kepada siswa dengan model pembelajaran yang memerlukan pengamatan siswa dengan mengamati gejala-gejala, menggolongkan, membuat dugaan, menjelaskan, dan menarik kesimpulan untuk sampai pada kompetensi pembelajaran. Model pembelajaran

*Correspondence:

Muh. Fahry Ince Ote

e-mail: muhfahryinceote @gmail.com

(c) 2020 the Author(s) retain the copyright of this article. This article is published under the terms of the Creative Commons Attribution License 4.0, which permits unrestricted non-commercial use, distribution, and reproduction in any medium, provided the original work is properly cited. 
yang sesuai antara lain adalah model pembelajaran discovery learning.

Balim (2009) menyatakan bahwa penggunaan metode penemuan pembelajaran merupakan salah satu variasi metode mengajar yang membuat siswa aktif dan guru membimbingnya, yang diyakini mampu meningkatkan kesuksesan siswa dan keterampilan pembelajaran lebih baik daripada metode pembelajaran tradisional. Model discovery learning adalah memahami konsep, arti, hubungan, melalui proses intuitif untuk akhirnya sampai kepada suatu kesimpulan. Discovery learning terjadi bila individu terlibat, terutama dalam penggunaan proses mentalnya untuk menemukan beberapa konsep dan prinsip (Budiningsih, 2005).

Intuitif adalah tindakan seseorang menggapai makna atau struktur suatu masalah, yang tidak menggantungkan secara eksplisit pada analisis dalam bidang keahliannya. Membuat dugaan dengan cepat, menghasilkan gagasan yang menarik sebelum disadari manfaatnya, dan mendapatkan akal dalam pambuktian, merupakan contoh-contoh intuitif. Intuitif dekat dengan suasana permainan, yang dapat menerima kesalahan sebagai sesuatu yang wajar (Abidin, 2010). Intuitif merupakan kegiatan yang lebih menghargai proses, yang tidak menekankan pentingnya jawaban benar saja (Etika, 2016), sehingga dapat disimpulkan bahwa kemampuan berpikir intuitif merupakan kemampuan untuk memecahkan masalah secara sepintas atau segera tanpa melakukan pembuktian secara formal. Kemampuan berpikir intuitif berkembang karena pengalaman. Semakin kaya dalam pengalaman, maka semakin kuat intuisi muncul dalam memberikan petunjuk untuk menyelesaikan suatu permasalahan.

Kemampuan berpikir intuitif poin utamanya terletak pada tahapan-tahapan discovery learning yaitu pada tahap pertama, ketiga dan keempat. Tahap pertama yaitu stimulation (pemberian rangsangan), tahap ketiga data collection (pengumpulan data) tahap keempat data processing (pengolahan data).

Sa'o (2016) menyampaikan bahwa munculnya berpikir intuitif pada pemecahan masalah matematika yang merupakan solusi untuk memperoleh penyelesaian masalah dengan benar. Oleh karena itu, dapat dikatakan bahwa berpikir intuitif adalah salah satu solusi untuk mengatasi rendahnya prestasi belajar matematika.

Yuni dkk. (2018) berpendapat bahwa proses menyelesaikan masalah matematika membutuhkan gagasan atau ide-ide awal berdasarkan kemampuan berpikir intuitif dengan penalaran matematis yang disebut dengan intuisi matematis.

Penelitian yang dilakukan Muniri (2013) menunjukkan bahwa kemampuan seseorang memahami dan sekaligus menemukan strategi yang tepat dan cepat dalam menyelesaikan masalah tersebut merupakan aktifitas mental yang ditopang oleh kecakapan berpikir intuitif yang muncul secara spontan, bersifat segera (immediate), global atau mungkin muncul secara tiba-tiba (sudently) dan tidak diketahui dari mana asalnya.

Giardino (2010) mengungkapkan bahwa intuisi matematika tergantung pada latar belakang pengetahuan dan keahlian, dan itu memungkinkan untuk melihat keumuman dari kesimpulan yang diperoleh dengan cara visualisasi.

Menurut Susilawati (2017) bahwa pendekatan eksplorasi berbasis intuisi dapat memfasilitasi proses intuisi, penemuan konsep, dan aplikasi konsep sehingga kemampuan pemecahan masalah matematis siswa lebih baik dari pada pembelajaran konvensional.

Hasil penelitian yang dilakukan oleh Fahtur (2017) menunjukkan bahwa model discovery learning berpengaruh penting terhadap kemampuan berpikir intuitif terutama pada pada kemampuan menyelesaikan masalah dengan pengetahuan dan pengalaman yang sudah dimiliki sebelumnya, dan generalisasi dari contoh atau konsep.

Tulisan ini dimaksudkan untuk melihat kemampuan berpikir intuitif siswa melalui model pembelajaran discovery learning pada materi koloid.

\section{Metode}

Kegiatan penelitian ini dilaksanakan di SMA Negeri 4 Model Palu, pada kelas XI IPA dengan jumlah sampel 35 siswa sebagai kelas replikasi 1 (XI IPA 3) dan 35 siswa sebagai kelas replikasi 2 (XI IPA 6). Teknik pengumpulan sampel yang digunakan adalah simple random sampling, yaitu pengambilan anggota sampel dari populasi dilakukan secara acak tanpa memperhatikan strata yang ada dalam populasi itu.

Desain penelitian ini adalah one-shot case study. Desain ini diberi perlakuan terhadap siswa kemudian dilakukan tes akhir atau postest terhadap kemampuan berpikir intuitif siswa.

Analisis data pada penelitian ini yaitu tes berpikir intuitif yang merupakan tes akhir (posttest).

\section{Hasil dan Pembahasan}

Penelitian mengenai penerapan model discovery leraning pada materi Koloid secara keseluruhan berdampak positif terhadap kemampuan berpikir intuitif siswa kelas XI IPA SMA Negeri 4 Palu. Hal ini diketahui dari data hasil tes berpikir intuitif berdasarkan indikator pada kelas replikasi 1 dan kelas replikasi 2. Data hasil tes berpikir intuitif berdasarkan indikator dapat dilihat pada Tabel 1 dan 2. 
Tabel 1. Deskripsi data kemampuan berpikir intuitif siswa kelas replikasi 1 berdasarkan indicator

\begin{tabular}{cccccc}
\hline $\begin{array}{c}\mathrm{N} \\
\mathrm{o}\end{array}$ & Indikator & $\mathrm{N}$ & Skor Total & $\begin{array}{c}\text { Skor } \\
\text { Siswa }\end{array}$ & $\begin{array}{c}\text { Persentase } \\
(\%)\end{array}$ \\
\hline 1 & $\begin{array}{l}\text { Kemampuan menyelesaikan masalah dengan jawaban } \\
\text { yang masuk akal }\end{array}$ & 35 & 140 & 121 & 86.43 \\
2 & $\begin{array}{l}\text { Kemampuan menyelesaikan masalah menggunakan } \\
\text { pengetahuan dan pengalaman yang sudah dimiliki } \\
\text { sebelumnya }\end{array}$ & 35 & 140 & 108 & 77.14 \\
3 & $\begin{array}{l}\text { Kemampuan menyelesaikan masalah berdasarkan } \\
\text { generalisasi dari contoh atau konsep }\end{array}$ & 35 & 560 & 473 & 84.46 \\
\hline
\end{tabular}

Tabel 2. Deskripsi data kemampuan berpikir intuitif siswa kelas replikasi 2 berdasarkan indicator

\begin{tabular}{cccccc}
\hline $\mathrm{N}$ & Indikator & $\mathrm{N}$ & $\begin{array}{r}\text { Skor } \\
\text { Total }\end{array}$ & $\begin{array}{c}\text { Skor } \\
\text { Siswa }\end{array}$ & $\begin{array}{c}\text { Persentase } \\
(\%)\end{array}$ \\
\hline 1 & $\begin{array}{l}\text { Kemampuan menyelesaikan masalah dengan jawaban } \\
\text { yang masuk akal }\end{array}$ & 35 & 140 & 74 & 52.85 \\
\hline 2 & $\begin{array}{l}\text { Kemampuan menyelesaikan masalah menggunakan } \\
\text { pengetahuan dan pengalaman yang sudah dimiliki } \\
\text { sebelumnya }\end{array}$ & 35 & 140 & 107 & 76.42 \\
\hline 3 & $\begin{array}{l}\text { Kemampuan menyelesaikan masalah berdasarkan } \\
\text { generalisasi dari contoh atau konsep }\end{array}$ & 35 & 560 & 470 & 83.92 \\
\hline
\end{tabular}

Berdasarkan Tabel 1 kemampuan berpikir intuitif siswa kelas replikasi 1 bahwa siswa yang mampu menyelesaikan masalah dengan jawaban yang masuk akal adalah sebesar $86.43 \%$ masuk dalam kategori sangat tinggi. Siswa yang mampu menyelesaikan masalah menggunakan pengetahuan dan pengalaman yang sudah dimiliki sebelumnya adalah sebesar $77.14 \%$ masuk dalam kategori tinggi, dan siswa yang mampu menyelesaikan masalah berdasarkan generalisasi dari contoh atau konsep adalah sebesar $84.46 \%$ masuk dalam kategori sangat tinggi.

Berdasarkan Tabel 1 maka secara visual kategori kemampuan berpikir intuitif siswa kelas replikasi 1 berdasarkan indikator dapat dilihat pada Gambar 1.

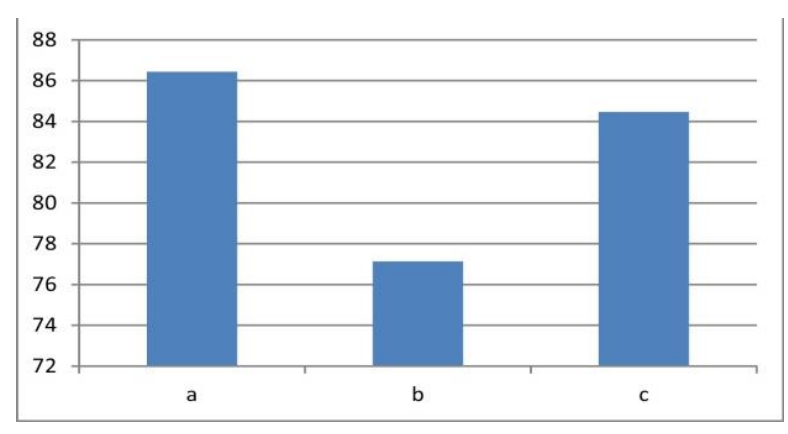

Gambar 1. Histogram kategori kemampuan berpikir intuitif siswa kelas replikasi 1 berdasarkan indikator $\mathrm{a}=$ Kemampuan menyelesaikan masalah dengan jawaban yang masuk akal $\mathrm{b}=$ Kemampuan menyelesaikan masalah menggunakan pengetahuan dan pengalaman yang sudah dimiliki sebelumnya $\mathrm{c}=$ Kemampuan menyelesaikan masalah berdasarkan generalisasi dari contoh atau konsep

Beradasarkan Tabel 2 kemampuan berpikir intuitif siswa kelas replikasi 2 bahwa siswa yang mampu menyelesaikan masalah dengan jawaban yang masuk akal adalah sebesar 52.85\% masuk dalam kategori sedang. Siswa yang mampu menyelesaikan masalah menggunakan pengetahuan dan pengalaman yang sudah dimiliki sebelumnya adalah sebesar $76.42 \%$ masuk dalam kategori tinggi, dan siswa yang mampu menyelesaikan masalah berdasarkan generalisasi dari contoh atau konsep 
adalah sebesar 83.92\% masuk dalam kategori sangat tinggi.

Berdasarkan Tabel 2 maka secara visual kategori kemampuan berpikir intuitif siswa kelas replikasi 1 berdasarkan indikator dapat dilihat pada Gambar 2.

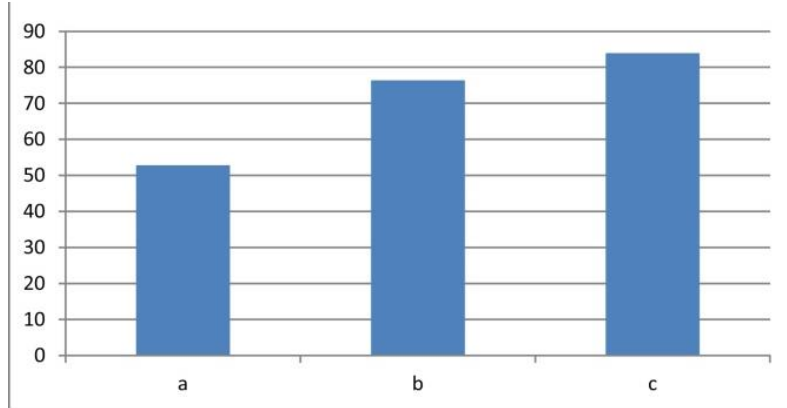

Gambar 2. Histogram kategori kemampuan berpikir intuitif siswa kelas replikasi 2 berdasarkan indikator

Hasil kerja yang telah dipaparkan diatas adalah kemampuan berpikir intuitif. Pada akhir proses pembelajaran, kelas replikasi 1 dan replikasi 2 diberikan posttest dengan instrumen soal yang sama untuk mengetahui kemampuan berpikir intuitifnya. Perbedaan cara menjawab soal siswa untuk masing-masing indikator kemampuan berpikir intuitif dideskripsikan sebagai berikut:

Indikator kemampuan menyelesaikan masalah dengan jawaban yang masuk akal. Pada indikator ini siswa menjelaskan dengan rinci jawaban yang dikerjakan. Kemampuan ini muncul yaitu terjadi pada tahap stimulasi. Pada tahap ini siswa dilatih untuk selalu memberikan tanggapan yang logis terhadap pendapat siswa lainnya terkait materi koloid. Sehingga siswa dapat menyelesaikan masalah berdasarkan jawaban yang masuk akal.

Indikator kemampuan menyelesaikan masalah menggunakan pengetahuan dan pengalaman yang sudah dimiliki sebelumnya. Pada indikator ini siswa mampu untuk menyelesaikan soal yang diberikan walaupun masih terdapat variasi jawaban. Pada soal ini banyak siswa yang menggunakan pengetahuannya mengenai contoh penggunaan koloid. Hal ini menunjukan bahwa siswa mampu menggunakan pengetahuan yang telah didapatkannya serta pengalaman sebelumnya untuk menjawab pertanyaan yang diberikan. Kemampuan ini muncul yaitu terjadi pada tahap pengumpulan data. Pada tahap ini siswa belajar secara aktif untuk menemukan sesuatu yang berhubungan dengan permasalahan yang dihadapi, dengan demikian secara tidak sengaja peserta didik menghubungkan masalah dengan pengetahuan yang telah dimiliki.

Indikator kemampuan menyelesaikan masalah berdasarkan generalisasi dari contoh atau konsep. Pada indikator ini siswa menggunakan kemampuan generalisasi dari konsep yang ada pada soal sehingga dapat ditemukan jawaban atas pertanyaan yang diberikan. Kemampuan ini muncul yaitu terjadi pada tahap pengolahan data. Pada tahap ini data olahan siswa merupakan kategorisasi yang berfungsi sebagai pembentukan konsep dan generalisasi. Dari generalisasi tersebut siswa akan mendapatkan pengetahuan baru tentang alternative jawaban/penyelasaian yang perlu mendapat buktian secara logis. Sehingga siswa dapat menyelesaikan masalah berdasakan generalisasi dari contoh atau konsep.

Berdasarkan uraian yang telah dijelaskan menunjukkan bahwa model discovery learning dapat diterapkan dalam pembelajaran kimia pada materi koloid. Karena pada kelas replikasi 1 dan kelas replikasi 2 memiliki tingkat kemampuan berpikir intuitif yang relatif sama, meskipun terdapat perbedaan dari tingkat kemampuan berpikir intuitif siswa dalam menyelesaikan masalah dengan jawaban yang masuk akal. Hal ini disebabkan karena pada kelas replikasi 2, pemebelajaran dimulai pada siang hari setelah mata yang menyebabkan siswa lelah dan mengantuk, sehingga siswa kurang memperhatikan saat pembelaran berlangsung.

Secara mendasar, penelitian ini setidaknya sudah membuktikan bahwa kemampuan berpikir intuitif bisa dipelajari dengan pemberian model pembelajaran discovery learning yang dapat meningkatkan kemampuan berpikir intuitif siswa. Hal tersebut sesuai dengan apa yang diungkapkan Fischbein (1999) bahwa pemberian pembelajaran yang tepat merupakan suatu upaya untuk mengembangkan kemampuan intuisi seseorang.

Hasil temuan pada penelitian ini melengkapi teori yang dikemukakan oleh Sukmana \& Wahyudin (2011) bahwa indikator yang sering muncul saat siswa menggunakan kemampuan berpikir intuitif ialah mampu menyelesaikan masalah dengan jawaban yang masuk akal, mampu menyelesaikan masalah menggunakan pengetahuan dan pengalaman yang sudah dimiliki sebelumnya, mampu menyelesaikan masalah berdasarkan generalisasi contoh atau konsep. 


\section{Kesimpulan}

Kemampuan berpikir intuitif siswa kelas replikasi 1 bahwa siswa yang mampu menyelesaikan masalah dengan jawaban yang masuk akal adalah sebesar $86.43 \%$ masuk dalam kategori sangat tinggi. Siswa yang mampu menyelesaikan masalah menggunakan pengetahuan dan pengalaman yang sudah dimiliki sebelumnya adalah sebesar $77.14 \%$ masuk dalam kategori tinggi, dan siswa yang mampu menyelesaikan masalah berdasarkan generalisasi dari contoh atau konsep adalah sebesar $84.46 \%$ masuk dalam kategori sangat tinggi, sedangkan kemampuan berpikir intuitif siswa kelas replikasi 2 bahwa siswa yang mampu menyelesaikan masalah dengan jawaban yang masuk akal adalah sebesar $52.85 \%$ masuk dalam kategori sedang. Siswa yang mampu menyelesaikan masalah menggunakan pengetahuan dan pengalaman yang sudah dimiliki sebelumnya adalah sebesar $76.42 \%$ masuk dalam kategori tinggi, dan siswa yang mampu menyelesaikan masalah berdasarkan generalisasi dari contoh atau konsep adalah sebesar 83.92\% masuk dalam kategori sangat tinggi.

\section{Ucapan Terima kasih}

Penulis mengucapkan terima kasih kepada Syam Zaini kepala SMA Negeri 4 Palu dan Burhan Dg. Situju guru mata pelajaran kimia SMA Negeri 4 Palu serta semua pihak yang banyak membantu penulis dalam menyelesaikan penelitian ini.

\section{Referensi}

Abidin, Z. (2011). Intuisi siswa madrasah ibtidaiyah (MI) dalam pemecahan masalah matematika divergen. Jurnal Pendidikan dan Pembelajaran Dasar, 4(1), 47-59.

Balim, A. G. (2009). The effects of discovery learning on students' success and inquiry learning skills. Eurasian Journal of Educational Research, 35, 1-20.

Budiningsih. (2005). Belajar dan pembelajaran. Jakarta: Rineka Cipta.

Etika. (2016). Intuisi siswa kelas VII SMP Negeri 1 Nganjuk dalam pemecahan masalah matematika ditinjau dari adversity quotient (AQ). Jurnal Elektronik Pembelajaran Matematika, 4(5), 563574.

Fahtur, R. S. (2017). Pengembangan instrumen dan analisis kemampuan berpikir intuitif matematis. Skripsi Tidak Diterbitkan. Jakarta: Universitas Islam Negeri Syarif Hidayatullah.

Fischbein, E. (1999). Intuitions and schemata in mathematical reasoning. Educational Studies in Mathematics, 38(1/3), 11-50.

Giardino, V. (2010). Intuition and visualizatioin in mathematical problem solving, An International Review of Philosophy, 29(1), 29-39.
Haeruman, L. D., Rahayu, W., \& Ambarwati, L. (2017). Pengaruh model discovery learning terhadap peningkatan kemampuan berpikir kritis matematis dan self-confidence ditinjau dari kemampuan awal matematis siswa SMA di Bogor Timur. Jurnal Pendidikan dan Pembelajaran Matematika, 10(2), 157-168.

Isnainiyah, S., Sukardjo, J. S., \& Yamtinah, S. (2015). Pembelajaran metode pembelajaran TGT (teams games tournament) berbantuan demonstrasi dan kreativitas terhadap prestasi belajar siswa pada pokok bahasan koloid kelas XI SMA N Sumpiuh semester genap tahun ajaran 2011/2012. Jurnal Pendidikan Kimia, 4(3), 1924.

Muniri. (2013). Karakteristik berpikir intuitif siswa dalam menyelesaikan masalah matematika. Seminar Nasional Matematika dan Pendidikan Matematika, 443-452.

Rahmi, Y. L., \& Alberida, H. (2017). Peningkatan keterampilan berpikir tingkat tinggi mahasiswa melalui penerapan asesmen portofolio pada mata kuliah telaah kurikulum dan buku ajar biologi. Bioeducation Journal, 1(1), 22-33.

Sari, D. N, Nurhayati, N. D., \& Redjeki, T. (2016). Penerapan pembelajaran team games tournaments dengan bantuan chemimagz untuk meningkatkan aktivitas dan prestasi belajar siswa pada materi kimia koloid kelas XI IPA 3 semester genap SMA Negeri Kebakkramat tahun ajaran 2014/2015, Jurnal Pendidikan Kimia, 5(1), 6470.

Sa'o, S. (2016). Berpikir intuitif sebagai solusi mengatasi rendahnya prestasi belajar matematika. Jurnal Review Pembelajaran Matematika, 1(1), 43-56.

Sirait, T., \& Hutabarat, W. (2015). Pengaruh model pembelajaran problem based learning dengan media power point terhadap hasil belajar kimia siswa SMA pada pokok bahasan konsep redoks. Jurnal Pendidikan Kimia, 7(2), 1-7.

Slameto. (2013). Belajar dan faktor-faktor yang mempengaruhinya. Jakarta: PT Rineka Cipta.

Sukmana, A., \& Wahyudin. (2011). A teaching material development for developing students intitive thinking through REACT contextual teaching approach. Jurnal Ilmiah Matematika, Statistika, 11(2), 75-81.

Susilawati, E., Syaf, A. H., \& Susilawati, W. (2017). Pendekatan eksplorasi berbasis intuisi pada kemampuan pemecahan masalah matematis. Jurnal Analisa, 3(2), 138-147.

Yuni, Y. Darhim \& Turmudi. (2018). Peningkatan berpikir intuisi dan penalaran matematis pembelajaran inquiry berbasis open-ended. Jurnal Pendidikan Matematika, 2(2), 107-126. 